\title{
Gelria glutamica gen. nov., sp. nov., a thermophilic, obligately syntrophic, glutamate-degrading anaerobe
}

\author{
${ }^{1}$ Laboratory of \\ Microbiology, Wageningen \\ University, H. van \\ Suchtelenweg 4, 6703 \\ CT Wageningen, \\ The Netherlands \\ 2 Wageningen Centre for \\ Food Science, PO Box 557, \\ 6700 AL Wageningen, \\ The Netherlands
}

\author{
Caroline M. Plugge, ${ }^{1}$ Melike Balk, ${ }^{1}$ Erwin G. Zoetendal ${ }^{1,2}$ \\ and Alfons J. M. Stams ${ }^{1}$
}

\begin{abstract}
Author for correspondence: Caroline M. Plugge. Tel: +31 317 482105. Fax: + 31317483829. e-mail: Caroline.Plugge@algemeen.micr.wag-ur.nl
\end{abstract}

\begin{abstract}
A novel anaerobic, Gram-positive, thermophilic, spore-forming, obligately syntrophic, glutamate-degrading bacterium, strain TGO', was isolated from a propionate-oxidizing methanogenic enrichment culture. The axenic culture was obtained by growing the bacterium on pyruvate. Cells were rod-shaped and non-motile. The optimal temperature for growth was 50-55 ${ }^{\circ} \mathrm{C}$ and growth occurred between 37 and $60^{\circ} \mathrm{C}$. The $\mathrm{pH}$ range for growth was 5.5-8 with optimum growth at pH 7. In pure culture, strain $\mathrm{TGO}^{\top}$ could grow on pyruvate, lactate, glycerol and several sugars. In co-culture with the hydrogenotrophic methanogen Methanobacterium thermautotrophicum strain Z-245, strain TGO' could grow on glutamate, proline and Casamino acids. Glutamate was converted to $\mathrm{H}_{2}, \mathrm{CO}_{2}$, propionate and traces of succinate. Strain $\mathrm{TGO}^{\top}$ was not able to utilize sulphate, sulphite, thiosulphate, nitrate or fumarate as electron acceptors. The G+C content was $33.8 \mathrm{~mol} \%$. Sequence analysis of the $16 \mathrm{~S}$ rDNA revealed that strain $\mathrm{TGO}^{\top}$ belongs to the thermophilic, endospore-forming anaerobes, though no close relations were found. Its closest relations were Moorella glycerini (92\%) and Moorella thermoacetica (90\%). Strain TGO' had an unusually long 165 rDNA of more than $1700 \mathrm{bp}$. The additional base pairs were found as long loops in the V1, V7 and V9 regions of the 16S rDNA. However, the loops were not found in the 16S rRNA. The name Gelria glutamica gen. nov., sp. nov. is proposed for strain TGO'.
\end{abstract}

Keywords: thermophilic bacteria, interspecies hydrogen transfer, obligate syntrophic glutamate oxidation, proline oxidation, propionate formation

\section{INTRODUCTION}

Because proteins are encountered in almost every ecosystem, the biodegradation of amino acids is a very important microbial process. The conversion of amino acids in methanogenic environments has been studied over the last 20 years, especially in temperate environments (Barker, 1981; Nagase \& Matsuo, 1982; McInerney, 1989). However, in moderately thermophilic methanogenic environments, the degradation of amino acids has not been studied in detail. Only a few bacterial species have been described to degrade amino acids under thermophilic conditions (Cheng et al.,

The GenBank accession number for the $16 \mathrm{~S}$ rDNA sequence of strain $\mathrm{TGO}^{\top}$ is AF321086.
1992; Örlygsson, 1994; Tarlera et al., 1997; Plugge et al., 2000).

Glutamate conversion under methanogenic conditions can occur in different ways (Table 1). The formation of acetate and butyrate as the organic end-products has been described for many anaerobes that belong mainly to the genus Clostridium. This type of conversion of glutamate is hydrogen independent. Other examples of hydrogen-independent glutamate conversions are the homoacetogenic fermentation (Dehning et al., 1989) and the reductive formation of propionate (Nanninga et al., 1987). The formation of hydrogen is more likely to occur in methanogenic environments, where hydrogen-scavenging methanogens convert the hydrogen to methane with the concomitant reduction of $\mathrm{CO}_{2}$. In the presence of methanogens, the free energy available from the overall reactions is higher (Table 1). Under 
Table 1. Change of free energy for the conversion of glutamate to various products at $55^{\circ} \mathrm{C}$ under anaerobic conditions

Energy changes were calculated using the van't Hoff equation, standard enthalpy values of compounds (Chang, 1977) and Gibbs' free energy changes at $298 \mathrm{~K}$ (Thauer et al., 1977). Values of $\Delta \mathrm{G}^{\prime}$ were calculated under standard conditions: $\mathrm{pH} 7,1 \mathrm{M}$ solutes, 1 atmosphere gases and $55^{\circ} \mathrm{C}(328 \mathrm{~K})$.

\begin{tabular}{|c|c|c|}
\hline \multirow[t]{2}{*}{ Reaction } & \multicolumn{2}{|c|}{$\Delta \mathbf{G}^{\prime}(\mathbf{k J})$} \\
\hline & $10^{5} \mathrm{~Pa} \mathrm{H}_{2}$ & $1 \mathrm{~Pa} \mathrm{H}_{2}$ \\
\hline Glutamate $^{-}+2 \mathrm{H}_{2} \mathrm{O} \rightarrow$ acetate $^{-}+\mathrm{HCO}_{3}^{-}+\frac{1}{2} \mathrm{H}^{+}+\mathrm{NH}_{4}^{+}+\frac{1}{2}$ butyrate - & $-61 \cdot 1$ & $-61 \cdot 1$ \\
\hline Glutamate $^{-}+3 \mathrm{H}_{2}^{2} \mathrm{O} \rightarrow 2$ acetate $^{-}+\mathrm{HCO}_{3}^{-}+\mathrm{H}^{+}+\mathrm{NH}_{4}^{+}+\mathrm{H}_{2}$ & $-41 \cdot 6$ & $-73 \cdot 1$ \\
\hline Glutamate $^{-}+2 \mathrm{H}_{2} \mathrm{O} \rightarrow 2 \frac{1}{4}$ acetate $^{-}+\frac{1}{2} \mathrm{HCO}_{3}^{-}+\frac{3}{4} \mathrm{H}^{+}+\mathrm{NH}_{4}^{+}$ & $-64 \cdot 0$ & $-64 \cdot 0$ \\
\hline Glutamate $^{-}+2 \mathrm{H}_{2} \mathrm{O} \rightarrow 1 \frac{2}{3}$ acetate $+\frac{1}{3}$ propionate $^{-}+\frac{2}{3} \mathrm{HCO}_{3}^{-}+\frac{2}{3} \mathrm{H}^{+}+\mathrm{NH}_{4}^{+}$ & $-69 \cdot 0$ & $-69 \cdot 0$ \\
\hline Glutamate $^{-}+4 \mathrm{H}_{2}^{-} \mathrm{O} \rightarrow$ propionate $^{-}+2 \mathrm{HCO}_{3}^{-}+\mathrm{NH}_{4}^{+}+2 \mathrm{H}_{2}$ & $-16 \cdot 0$ & $-79 \cdot 0$ \\
\hline
\end{tabular}

standard conditions, these reactions yield small amounts of energy. In particular, the exclusive formation of propionate from glutamate is very difficult, since the free energy at $55^{\circ} \mathrm{C}$ is only $-16.0 \mathrm{~kJ}(\mathrm{~mol}$ glutamate $^{-1}$ (Table 1). It is highly unlikely that a single organism can perform this reaction. However, in a methanogenic consortium, the hydrogen formed is consumed via interspecies hydrogen transfer and the energy that becomes available from this reaction increases to $-79 \cdot 0 \mathrm{~kJ}$ (mol glutamate $)^{-1}$.

Earlier research indicated the presence of a propionateforming, obligately syntrophic bacterium in a thermophilic, syntrophic, glutamate-degrading, propionateoxidizing enrichment (Stams et al., 1992). From this mixed culture, we isolated a bacterium that produced propionate as the major product from glutamate, in addition to traces of succinate. In this paper, we present detailed information about the organism and we propose to name the organism Gelria glutamica gen. nov., sp. nov.

\section{METHODS}

Strains and source of organisms. The glutamate-degrading strain $\mathrm{TGO}^{\mathrm{T}}$ was isolated from a thermophilic, syntrophic, propionate-oxidizing enrichment culture as described by Stams et al. (1992). Strain TPO, a syntrophic, propionateoxidizing bacterium, was isolated from the same enrichment culture. Moorella thermoacetica DSM $521^{\mathrm{T}}$ and Moorella glycerini DSM $11254^{\mathrm{T}}$ were obtained from the DSMZ. Methanobacterium thermautotrophicum Z-245 (= DSM 3720) has been used before; this methanogen was recently renamed Methanothermobacter thermautotrophicus Z-245 (Wasserfallen et al., 2000).

Media and cultivation. A bicarbonate-buffered medium with the following composition was used $\left(1^{-1}\right)$ : $0.4 \mathrm{~g} \mathrm{KH}_{2} \mathrm{PO}_{4}$, $0.53 \mathrm{~g} \mathrm{Na}_{2} \mathrm{HPO}_{4}, 0.3 \mathrm{~g} \mathrm{NH}_{4} \mathrm{Cl}, 0.3 \mathrm{~g} \mathrm{NaCl}, 0 \cdot 1 \mathrm{~g} \mathrm{MgCl}_{2}$. $6 \mathrm{H}_{2} \mathrm{O}, 0 \cdot 11 \mathrm{~g} \mathrm{CaCl}{ }_{2} \cdot 2 \mathrm{H}_{2} \mathrm{O}, 1 \mathrm{ml}$ alkaline trace element solution, $1 \mathrm{ml}$ acid trace element solution, $1 \mathrm{ml}$ vitamin solution, $0.5 \mathrm{mg}$ resazurin, $4 \mathrm{~g} \mathrm{NaHCO}, 0.25 \mathrm{~g} \mathrm{Na}_{2} \mathrm{~S}$. $7-9 \mathrm{H}_{2} \mathrm{O}$ and $0.5 \mathrm{~g}$ yeast extract. The trace elements and vitamins were as described in Stams et al. (1993). All compounds were heat-sterilized except for the vitamins and the solution of $\mathrm{Na}_{2} \mathrm{~S}$. 7-9 $\mathrm{H}_{2} \mathrm{O}$, which were filter-sterilized. Incubations were done in serum bottles sealed with butyl rubber stoppers (Rubber bv) and a gas phase of $182 \mathrm{kPa}$ $\mathrm{N}_{2} / \mathrm{CO}_{2}(80: 20, \mathrm{v} / \mathrm{v})$. For the cultivation of methanogens, a gas phase of $182 \mathrm{kPa} \mathrm{H} / \mathrm{CO}_{2}(80: 20, \mathrm{v} / \mathrm{v})$ was used and, after growth, the gas phase was changed to $\mathrm{N}_{2} / \mathrm{CO}_{2}$. Organic substrates were added from anaerobic sterile stock solutions to final concentrations of $20 \mathrm{mM}$ (unless otherwise stated). To obtain an axenic culture, soft agar ( $0.7-0.8 \%$ agar noble; Difco) was added to the medium described above, supplemented with $20 \mathrm{mM}$ pyruvate as the carbon source. Light microscopy confirmed purity.

For the reconstitution experiments with axenic cultures of strain $\mathrm{TGO}^{\mathrm{T}}(0.5 \%, \mathrm{v} / \mathrm{v})$, strain $\mathrm{TPO}(2 \%, \mathrm{v} / \mathrm{v})$ and Methanobacterium thermautotrophicum Z-245 (2\%, v/v) were inoculated in medium with $20 \mathrm{mM}$ glutamate.

Temperature and $\mathbf{p H}$. The temperature optimum was determined in bicarbonate-buffered medium containing $20 \mathrm{mM}$ pyruvate at $\mathrm{pH} 7$ and duplicate bottles were incubated at temperatures ranging from 30 to $75^{\circ} \mathrm{C}$. The $\mathrm{pH}$ optimum was tested in medium by adding $0 \cdot 15 \mathrm{~g} \mathrm{KH}_{2} \mathrm{PO}_{4} \mathrm{l}^{-1}$ instead of sodium bicarbonate. The $\mathrm{pH}$ value of the medium containing $20 \mathrm{mM}$ pyruvate was adjusted with $\mathrm{NaOH}$ or $\mathrm{HCl}$ under the $\mathrm{N}_{2}$ atmosphere. Duplicate bottles were incubated at $55^{\circ} \mathrm{C}$ at $\mathrm{pH}$ values ranging from $4 \cdot 5$ to $9 \cdot 5$. For determinations of the temperature and $\mathrm{pH}$ optimum, $\mathrm{OD}_{600}$ and acetate production were measured as indicators for growth.

Growth and substrate utilization. Utilization of substrates by strain $\mathrm{TGO}^{\mathrm{T}}$ in pure culture and in co-culture with Methanobacterium thermautotrophicum Z-245 was determined by monitoring growth and substrate depletion as well as product formation. All incubations were performed at $55{ }^{\circ} \mathrm{C}, \mathrm{pH} 7$. The effect of electron acceptors on the growth of strain $\mathrm{TGO}^{\mathrm{T}}$ was tested in medium with $20 \mathrm{mM}$ glutamate. $\mathbf{G}+\mathbf{C}$ content. Isolation and purification of genomic DNA was carried out according to Marmur (1961). The G+C content of the DNA was analysed using thermal denaturation as described by Owen et al. (1969).

16S rDNA sequence analysis. Total DNA was extracted from strain $\mathrm{TGO}^{\mathrm{T}}$ as described previously (Zoetendal et al., 1998). PCR was performed with the bacterial primers $7 \mathrm{f}$ and $1510 \mathrm{r}$ (Lane, 1991) by using the Taq DNA polymerase kit (Life Technologies) to amplify the bacterial $16 \mathrm{~S}$ rDNA. PCR products were purified with the Qiaquick PCR purification kit (Qiagen) according to the manufacturer's instructions. Primers 538r, 1100r (Lane, 1991) and 968f (Nübel et al., 1996) labelled with Infrared Dye 41 (MWG-Biotech) were 
used as sequencing primers. The sequences were analysed automatically on a LI-COR DNA sequencer 4000L and corrected manually. Phylogenetic analysis and tree construction were performed with the programs of the ARB software package (Strunk \& Ludwig, 1991). FASTA homology searches with sequences of the EMBL and GenBank DNA databases were performed and the results were compared with those obtained with the ARB programs. Because strain $\mathrm{TGO}^{\mathrm{T}}$ had additional loops in several regions of the $16 \mathrm{~S}$ rDNA, we did the database comparison with the complete sequence of $1725 \mathrm{bp}$ and also with the sequence without the additional loops.

RNA isolation, RT-PCR and dot-blot hybridizations. RNA was extracted from strain TGO $^{\mathrm{T}}$ as described by Zoetendal et al. (1998). Specific probes targeting the V1, V7 and V9 regions of the $16 \mathrm{~S}$ rDNA of strain $\mathrm{TGO}^{\mathrm{T}}$ were applied in order to investigate whether such additional loops were also present in the $16 \mathrm{~S}$ rRNA. The sequences of these oligonucleotides were 5'-GCTCTTGGGCCTTTTGAA-3' (V1 region), 5'-GTTAACCCTCTGGCTTTG-3' (V7 region) and 5'-CTCAATCCGCAAGTTTAA-3' (V9 region). Primer 538r (Lane, 1991) was used as a positive control for Eubacteria. Dot-blot hybridizations were performed with strain $\mathrm{TGO}^{\mathrm{T}}$, Moorella thermoacetica, Moorella glycerini and Escherichia coli as described by Oude Elferink et al. (1997). All membranes were hybridized overnight at $40^{\circ} \mathrm{C}$.

RT-PCR of the 16S rRNA genes of strain $\mathrm{TGO}^{\mathrm{T}}$, Moorella thermoacetica, Moorella glycerini and Escherichia coli was performed by means of bacterial primers $7 \mathrm{f}$ and 1510r using the Access RT-PCR system (Promega). Prior to the RTPCR amplification, the samples were incubated with RNasefree DNase (Promega) to remove all traces of DNA. The integrity and size of the nucleic acids were determined visually after electrophoresis on a $1.2 \%$ agarose gel containing ethidium bromide in the presence of markers and compared with the $16 \mathrm{~S}$ rDNA of strain $\mathrm{TGO}^{\mathrm{T}}$.

Other methods. Gases and organic acids were analysed by GC and HPLC as described by Plugge et al. (2000). Amino acids were analysed by HPLC as described by Kengen \& Stams (1994). Occasionally, glutamate was determined enzymically with glutamate dehydrogenase as described by Bernt \& Bergmeyer (1974). Ammonium was analysed by the indophenol-blue method (Hanson \& Philips, 1981). Inorganic compounds tested as electron acceptors were analysed by HPLC as described by Scholten \& Stams (1995). Gram and flagella staining were done by standard procedures as described previously (Plugge et al., 2000).

\section{RESULTS AND DISCUSSION}

\section{Isolation of the glutamate-oxidizing strain $\mathrm{TGO}^{\top}$}

A thermophilic, syntrophic, propionate-oxidizing enrichment, as described by Stams et al. (1992), was also able to convert glutamate to acetate, $\mathrm{NH}_{4}^{+}, \mathrm{HCO}_{3}^{-}$and $\mathrm{CH}_{4}$. When the enrichment culture was growing on glutamate, a small, rod-shaped bacterium became predominant. It was not possible to obtain the bacterium in pure culture by adding an inhibitor of methanogenesis (bromoethanesulphonic acid, BES) to the enrichment culture. No degradation of glutamate was observed when BES was added. The bacterium could be purified by serial dilution in media containing agar $(0.7-0.8 \%)$ with pyruvate as the organic substrate. The colonies that appeared in the agar and on

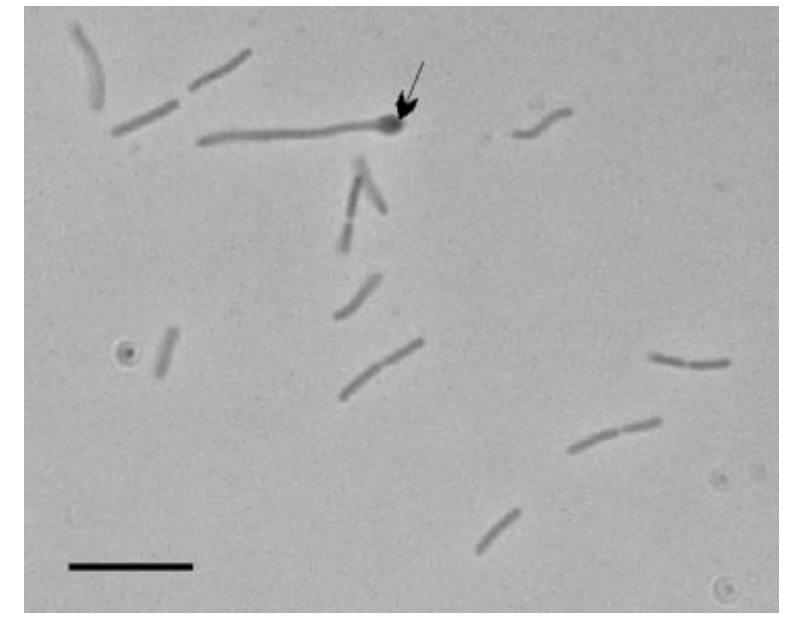

Fig. 1. Phase-contrast micrograph of strain $\mathrm{TGO}^{\top}$ grown on pyruvate. The arrow indicates the start of spore formation. Bar, $5 \mu \mathrm{m}$.

the surface of the agar were $0 \cdot 7-1 \cdot 0 \mathrm{~mm}$ in diameter. The colonies were white and round at the surface and lens-shaped in the agar. A single colony picked from the agar grew in medium containing pyruvate and with $0.05 \%$ yeast extract. Repeated transfer from liquid medium to soft-agar medium resulted in an axenic culture of a strain designated $\mathrm{TGO}^{\mathrm{T}}$. This strain was characterized further.

\section{Morphology and cellular characterization}

The isolated strain $\mathrm{TGO}^{\mathrm{T}}$ is a rod-shaped, sporeforming organism. The Gram stain was positive. Cells were $0.5 \mu \mathrm{m}$ in diameter and $1-1.5 \mu \mathrm{m}$ in length when grown on pyruvate (Fig. 1). If the bacterium was grown on glucose, the cells were $0.5 \mu \mathrm{m}$ in diameter and $3-20 \mu \mathrm{m}$ in length. Spores were located terminally and were $0.5 \times 0.5 \mu \mathrm{m}$ in size and developed in the lateexponential phase. Motility was never observed, nor were flagella found.

\section{Physiological characterization}

Strain $\mathrm{TGO}^{\mathrm{T}}$ was able to grow on glutamate only in the presence of the methanogenic archaeon Methanobacterium thermautotrophicum Z-245. Glutamate $(15 \mathrm{mM})$ was converted to propionate $(12.9 \mathrm{mM})$, succinate $(1.0 \mathrm{mM}), \mathrm{NH}_{4}^{+}(14.9 \mathrm{mM})$ and $\mathrm{CH}_{4}(8.9$ $\mathrm{mM})$. The carbon and electron recovery were respectively 93 and $98 \%$ (excluding the biomass formed). The doubling time of strain $\mathrm{TGO}^{\mathrm{T}}$ in co-culture with Methanobacterium thermautotrophicum Z-245 on glutamate was 0.23 day $^{-1}$. Several thermophilic bacteria are known to utilize glutamate with the concomitant production of $\mathrm{H}_{2}$, but these organisms also grow in pure culture on glutamate. Caloramator proteoclasticus, Caloramator coolhaasii and Thermanaerovibrio acidaminovorans (Cheng et al., 1992; Tarlera \& Stams, 1999; Plugge et al., 2000) are examples of such thermophilic glutamate-degrading organisms. In pure 

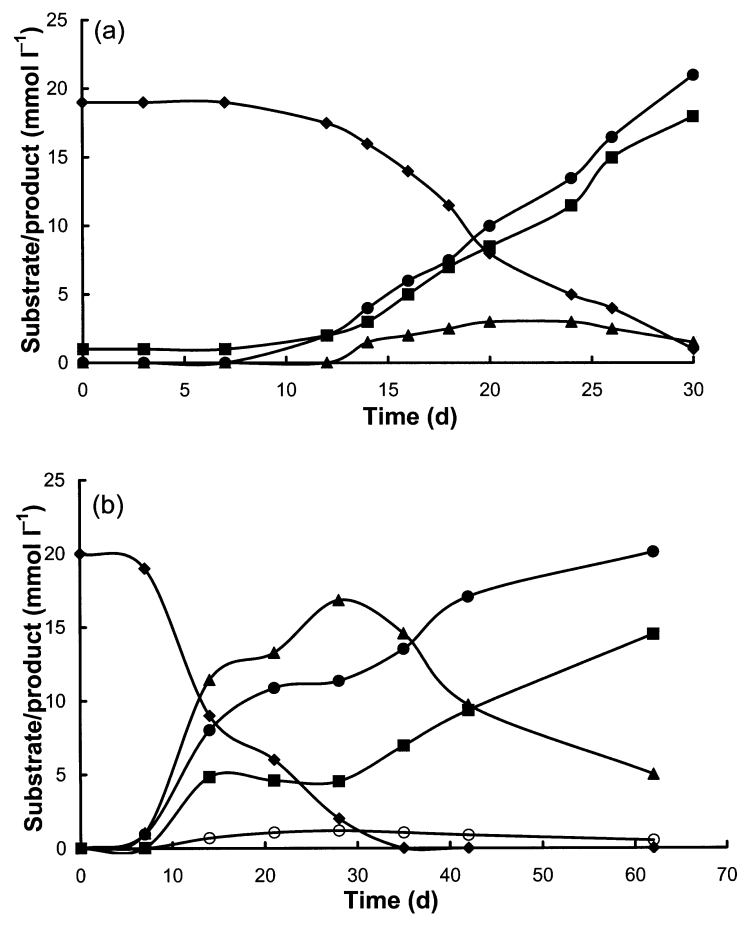

Fig. 2. Utilization of glutamate $(\diamond)$ and production of propionate $(\boldsymbol{\Delta})$, acetate $(\boldsymbol{\square})$, succinate $(\mathrm{O})$ and $\mathrm{CH}_{4}(\boldsymbol{O})$ by a consortium of strain $\mathrm{TGO}^{\top}$, strain TPO and Methanobacterium thermautotrophicum Z-245. (a) Original enrichment culture as described by Stams et al. (1992). (b) Co-culture inoculated with $0.5,2$ and $0.5 \%(\mathrm{v} / \mathrm{v})$ of pure cultures of strain $\mathrm{TGO}^{\top}$, strain TPO and Methanobacterium thermautotrophicum strain Z-245.

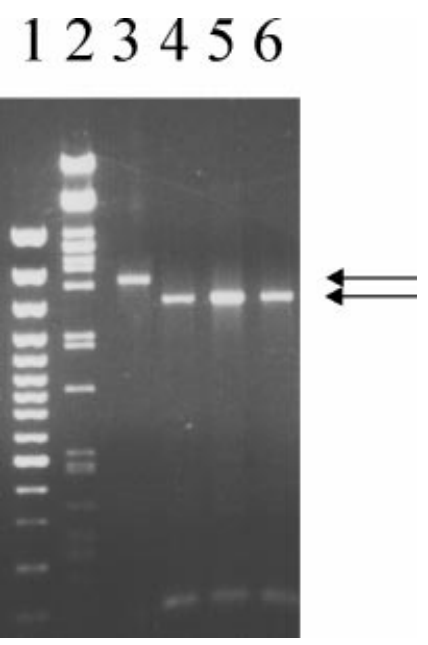

Fig. 3. Agarose gel (1.2\%) showing size and integrity of reamplified $16 \mathrm{~S}$ rDNA (lane 3 ) and rRNA (lane 4) of strain TGO ${ }^{\top}$ and 16S rRNA of Moorella glycerini (lane 5) and Moorella thermoacetica (lane 6). Markers: Gene Ruler 100 bp DNA ladder (lane 1) and phage $\lambda$ DNA digested with Pstl (lane 2).

culture, they form acetate, $\mathrm{NH}_{4}^{+} \mathrm{CO}_{2}$ and $\mathrm{H}_{2}$. Thermanaerovibrio acidaminovorans also forms propionate in pure culture. When Thermanaerovibrio acidamino- vorans is grown in co-culture with a methanogen, the products formed from glutamate conversion shift in favour of propionate formation. However, considerable amounts of acetate are still formed. Examples of mesophilic glutamate-degrading organisms that show the same degradation products as Thermanaerovibrio acidaminovorans are Acidaminobacter hydrogenoformans and Aminobacterium mobile (Stams \& Hansen, 1984; Baena et al., 2000). Like strain $\mathrm{TGO}^{\mathrm{T}}$, Aminobacterium mobile only grows on glutamate in the presence of a hydrogen scavenger.

Strain $\mathrm{TGO}^{\mathrm{T}}$ is the first example of an organism that is unable to form acetate from glutamate and forms mainly propionate. As a consequence, the organism has to grow in a syntrophic co-culture with a methanogen, since the free energy under standard conditions is only slightly negative (Table 1). It is unclear why strain $\mathrm{TGO}^{\mathrm{T}}$ does not form acetate from glutamate, even though acetate production could be detected after growth on several sugars, lactate and pyruvate. The formation of traces of succinate during glutamate utilization suggests that direct oxidation takes place via $\alpha$-ketoglutarate and succinyl-CoA. This pathway was also suggested to be used in propionate formation in Thermanaerovibrio acidaminovorans and Acidaminobacter hydrogenoformans (Cheng et al., 1992; Stams \& Hansen, 1984).

Yeast extract (minimum $0.02 \%$ ) was required for growth. Pyruvate was converted by strain $\mathrm{TGO}^{\mathrm{T}}$ to acetate, propionate, succinate (traces), $\mathrm{H}_{2}$ and $\mathrm{CO}_{2}$. Glycerol was utilized slowly by the pure culture but, in co-culture, glycerol was converted rapidly to acetate, traces of propionate and $\mathrm{CH}_{4}$.

Other substrates that could be used by the pure culture of $\mathrm{TGO}^{\mathrm{T}}$ were lactate, arabinose, fructose, galactose, glucose, maltose, mannitol, rhamnose and sucrose. Sugars were converted mainly to acetate and propionate with the formation of traces of hydrogen and formate.

In co-culture with the methanogen Methanobacterium thermautotrophicum Z-245, strain $\mathrm{TGO}^{\mathrm{T}}$ could also grow on Casamino acids, $\alpha$-ketoglutarate and proline. Proline $(18.6 \mathrm{mM})$ was degraded to propionate $(17 \cdot 3$ $\mathrm{mM}), \mathrm{NH}_{4}^{+}(18.2 \mathrm{mM})$ and $\mathrm{H}_{2}(27.2 \mathrm{mM})$ and the amount of hydrogen formed was calculated from the amount of methane measured. Anaerobic proline oxidation has been reported for two other bacteria. Desulfobacterium vacuolatum (Rees et al., 1998), a versatile amino acid-utilizing sulphate reducer, and Geovibrio ferrireducens (Caccavo et al., 1996), an ironreducing bacterium, can couple the oxidation of proline to sulphate reduction and dissimilatory Fe(III) reduction, respectively. The study of fermentative proline utilization by anaerobes has focussed on its use as an electron acceptor (McInerney, 1989). Strain $\mathrm{TGO}^{\mathrm{T}}$ might be able to convert proline to glutamate with the reverse reactions of proline synthesis via glutamate semialdehyde. 


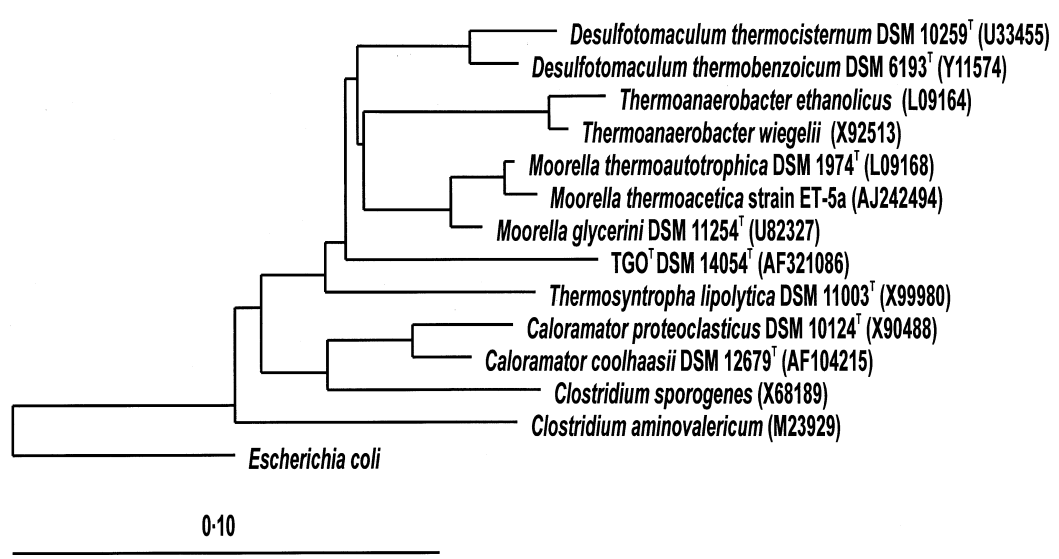

Fig. 4. Phylogenetic tree showing the position of strain $\mathrm{TGO}^{\top}$ among representatives of thermophilic, anaerobic spore-forming genera. The tree is based on a distance matrix of $16 \mathrm{~S}$ rRNA sequences and was constructed using the neighbour-joining method corrected by the method of Felsenstein (1982). Bar, $0 \cdot 1$ (evolutionary distance).

No growth of strain $\mathrm{TGO}^{\mathrm{T}}$ was observed in pure culture or in co-culture with Methanobacterium thermautotrophicum Z-245 on aspartate, alanine, lysine, threonine, leucine, tyrosine, glycine, fumarate, malate, succinate, propionate, acetate, methanol, ethanol, propanol, butanol, acetone, benzoate, starch or $\mathrm{H}_{2} / \mathrm{CO}_{2}$. The following mixtures of amino acids were tested but were not utilized by the pure culture of strain $\mathrm{TGO}^{\mathrm{T}}$ : alanine + glycine, alanine + arginine, alanine + proline, leucine + glycine, leucine + arginine, leucine + proline, $\mathrm{H}_{2}+$ glycine, $\mathrm{H}_{2}+$ arginine and $\mathrm{H}_{2}+$ proline. The strain could not grow in the presence of traces of oxygen, nor could sulphate, sulphite, thiosulphate or nitrate serve as electron acceptors.

Strain $\mathrm{TGO}^{\mathrm{T}}$ could grow on glucose between 37 and $60{ }^{\circ} \mathrm{C}$ with an optimum at $50-55^{\circ} \mathrm{C}$. The $\mathrm{pH}$ range for growth was 5.5-8, with optimum growth at $\mathrm{pH} 7$.

\section{Reconstitution of the original consortium from axenic cultures of strain $\mathrm{TGO}^{\top}$, strain TPO and Methanobacterium thermautotrophicum Z-245}

In order to investigate glutamate utilization as originally observed in the propionate-oxidizing enrichment culture, we performed reconstitution experiments with three axenic cultures: strain $\mathrm{TGO}^{\mathrm{T}}$, strain TPO (the syntrophic propionate-oxidizing organism) and Methanobacterium thermautotrophicum Z-245. In the original enrichment culture, glutamate was degraded to acetate, $\mathrm{CH}_{4}, \mathrm{NH}_{4}^{+}$and $\mathrm{CO}_{2}$, with the intermediate production of propionate (Fig. 2a). The stoichiometry of glutamate conversion was:

$$
\begin{aligned}
\text { Glutamate }^{-}+3 \frac{1}{4} \mathrm{H}_{2} \mathrm{O} \rightarrow \text { acetate }^{-} & +1 \frac{1}{4} \mathrm{CH}_{4}+1 \frac{3}{4} \mathrm{HCO}_{3}^{-} \\
& +\frac{3}{4} \mathrm{H}^{+}+\mathrm{NH}_{4}^{+}
\end{aligned}
$$

In the reconstitution experiments, glutamate was consumed according to the stoichiometry described above (Fig. 2b). This indicated that the axenic cultures of strain $\mathrm{TGO}^{\mathrm{T}}$ and strain TPO had the same physiological capabilities as in the original enrichment cultures.

\section{Phylogeny}

The nucleotide sequence (1725 bp) of the 16S rDNA of strain $\mathrm{TGO}^{\mathrm{T}}$ was analysed and it revealed that this organism belongs to the subphylum of Gram-positive, endospore-forming, thermophilic, anaerobic bacteria. Sequence alignment revealed that strain $\mathrm{TGO}^{\mathrm{T}}$ had additional loops in the V1, V7 and V9 helices of the 16S rDNA. There are examples of other organisms with 16S rDNA that exceeds the mean length of $1500 \mathrm{bp}$. In thermophiles, it is not unusual that the $16 \mathrm{~S}$ rDNA is longer (Rainey et al., 1996). Dot-blot hybridizations with specific oligonucleotides against these regions showed no hybridization with 16S rRNA from strain $\mathrm{TGO}^{\mathrm{T}}$, Moorella glycerini, Moorella thermoacetica and Escherichia coli. The positive control with primer $538 \mathrm{r}$ reacted with all $16 \mathrm{~S}$ rRNA molecules. This indicated that the loops were not transcribed from the $16 \mathrm{~S}$ rDNA to the $16 \mathrm{~S}$ rRNA of strain $\mathrm{TGO}^{\mathrm{T}}$. Comparison of the size of the 16S rDNA and 16S rRNA showed that the sizes were respectively 1700 and $1500 \mathrm{bp}$. This confirms the absence of the loops in the $16 \mathrm{~S}$ rRNA observed with the dot-blot hybridizations (Fig. 3). It is unclear how the transcription of the rRNA is regulated.

Sequence analysis showed that strain $\mathrm{TGO}^{\mathrm{T}}$ is only distantly related to Moorella glycerini and Moorella thermoacetica (Slobodkin et al., 1997; Collins et al., 1994), with respective levels of similarity of 92 and $90 \%$. The similarities were calculated with the use of the 16S rDNA sequence of strain $\mathrm{TGO}^{\mathrm{T}}$ without the additional loops. A phylogenetic tree showing the relationship of strain $\mathrm{TGO}^{\mathrm{T}}$ and other related species is depicted in Fig. 4.

The $\mathrm{G}+\mathrm{C}$ content of strain $\mathrm{TGO}^{\mathrm{T}}$ was $33.8 \mathrm{~mol} \%$.

\section{Taxonomy}

Our findings indicate that strain $\mathrm{TGO}^{\mathrm{T}}$ differs physiologically and phylogenetically from previously described species. Strain $\mathrm{TGO}^{\mathrm{T}}$ is phylogenetically most similar to the genus Moorella (90-92\% similarity), but 
the phylogenetic relationship is not sufficiently close to classify strain $\mathrm{TGO}^{\mathrm{T}}$ in this genus. Also, the ability of strain $\mathrm{TGO}^{\mathrm{T}}$ to form solely propionate from glutamate separates it from members of this genus. Therefore, we propose a novel genus and species, Gelria glutamica gen. nov., sp. nov.

\section{Description of Gelria gen. nov.}

Gelria (Gel.ri'a. N.L. fem. n. Gelria Gelre or Gelderland, one of the 12 provinces of The Netherlands, in which Wageningen is located).

Non-motile, Gram-positive rods. Formation of terminal spores. Strictly anaerobic. Moderately thermophilic. Saccharolytic growth in pure culture. Hydrogen formed can be transferred to methanogenic partner. Habitat: methanogenic granular sludge. Type species: Gelria glutamica.

\section{Description of Gelria glutamica sp. nov.}

Gelria glutamica (glu.ta'mi.ca. N.L. n. acidum glutamicum glutamic acid; N.L. fem. adj. glutamica referring to glutamic acid, on which the bacterium grows).

Cells are $0.5 \times 0.5-6 \mu \mathrm{m}$, varying depending on the growth substrate. In pure culture, the cells can grow on pyruvate, lactate, glycerol, glucose, rhamnose and galactose. In syntrophic association with a hydrogenotrophic methanogen, the organism can utilize glutamate, $\alpha$-ketoglutarate, proline, Casamino acids and a variety of sugars. Glutamate and proline are oxidized to propionate, $\mathrm{H}_{2}, \mathrm{NH}_{4}^{+}$and $\mathrm{CO}_{2}$. Sugars are converted to acetate, propionate, $\mathrm{CO}_{2}$ and $\mathrm{H}_{2}$ as main products. Growth occurs between 37 and $60^{\circ} \mathrm{C}$ with optimum growth at $50-55^{\circ} \mathrm{C}$ and at $\mathrm{pH} 5 \cdot 5-8$ (optimum $\mathrm{pH} 7$ ). The DNA $\mathrm{G}+\mathrm{C}$ content is $33 \cdot 8 \mathrm{~mol} \%$.

The type strain is $\mathrm{TGO}^{\mathrm{T}}\left(=\mathrm{DSM} 14054^{\mathrm{T}}=\mathrm{ATCC}\right.$ BAA-262 ${ }^{\mathrm{T}}$ ).

\section{ACKNOWLEDGEMENTS}

The determination of the $\mathrm{G}+\mathrm{C}$ content by $\mathrm{Dr} \mathrm{A}$. Lysenko at the Institute of Microbiology of the Russian Academy of Sciences in Moscow is greatly appreciated.

\section{REFERENCES}

Baena, S., Fardeau, M.-L., Labat, M., Ollivier, B., Garcia, J.-L. \& Patel, B. K. C. (2000). Aminobacterium mobile sp. nov., a new anaerobic amino-acid-degrading bacterium. Int J Syst Evol Microbiol 50, 259-264.

Barker, H. A. (1981). Amino acid degradation by anaerobic bacteria. Annu Rev Biochem 50, 23-40.

Bernt, E. \& Bergmeyer, H. U. (1974). L-Glutamate. In Methods of Enzymatic Analysis, pp. 1704-1708. Edited by H. U. Bergmeyer. Weinheim: Verlag Chemie.

Caccavo, F., Jr, Coates, J. D., Rossello-Mora, R. A., Ludwig, W., Schleifer, K. H., Lovley, D. R. \& McInerney, M. J. (1996). Geovibrio ferrireducens, a phylogenetic distinct dissimilatory Fe(III)-reducing bacterium. Arch Microbiol 165, 370-376.

Chang, R. (1977). Physical Chemistry with Applications to Biological Systems. New York: Macmillan.
Cheng, G., Plugge, C. M., Roelofsen, W., Houwen, F. P. \& Stams, A. J. M. (1992). Selenomonas acidaminovorans sp. nov., a versatile thermophilic proton-reducing anaerobe able to grow by decarboxylation of succinate to propionate. Arch Microbiol 157, 169-175.

Collins, M. D., Lawson, P. A., Willems, A., Cordoba, J. J., Fernandez-Garayzabal, J., Garcia, P., Cai, J., Hippe, H. \& Farrow, J. A. E. (1994). The phylogeny of the genus Clostridium: proposal of five new genera and eleven new species combinations. Int J Syst Bacteriol 44, 812-826.

Dehning, I., Stieb, M. \& Schink, B. (1989). Sporomusa malonica sp. nov., a homoacetogenic bacterium growing by decarboxylation of malonate or succinate. Arch Microbiol 151, 421-426.

Felsenstein, J. (1982). Numerical methods for interfering evolutionary trees. $Q$ Rev Biol 57, 379-404.

Hanson, R. S. \& Phillips, G. B. (1981). Ammonium by indophenol blue reaction. In Manual of Methods for General Bacteriology, pp. 356-357. Edited by P. Gerhardt, R. G. E. Murray, R. N. Costilow, E. W. Nester, W. A. Wood, N. R. Krieg \& G. B. Phillips. Washington, DC: American Society for Microbiology.

Kengen, S. W. M. \& Stams, A. J. M. (1994). Formation of L-alanine as a reduced end product in carbohydrate fermentation by the hyperthermophilic archeon Pyrococcus furiosus. Arch Microbiol 161, 168-175.

Lane, D. J. (1991). 16S/23S rDNA sequencing, In Nucleic Acid Techniques in Bacterial Systematics, pp. 115-175. Edited by E. Stackebrandt \& M. Goodfellow. Chichester: Wiley.

Marmur, J. (1961). Procedure for the isolation of desoxyribonucleic acid from microorganisms. J Mol Biol 3, 208-218.

Mclnerney, M. J. (1989). Anaerobic hydrolysis and fermentation of fats and proteins. In Microbiology of Anaerobic Bacteria, pp. 373-415. Edited by A. J. B. Zehnder. New York: Wiley.

Nagase, M. \& Matsuo, T. (1982). Interaction between amino acid degrading bacteria and methanogenic bacteria in anaerobic digestion. Biotechnol Bioeng 24, 2227-2239.

Nanninga, H. J., Drenth, W. J. \& Gottschal, J. C. (1987). Fermentation of glutamate by Selenomonas acidaminophila sp. nov. Arch Microbiol 147, 152-157.

Nübel, U., Engelen, B., Felske, A., Snaidr, J., Wieshuber, A., Amann, R. I., Ludwig, W. \& Backhaus, H. (1996). Sequence heterogeneities of genes encoding 16S rRNAs in Paenibacillus polymyxa detected by temperature gradient gel electrophoresis. J Bacteriol 178, 5636-5643.

Örlygsson, J. (1994). The role of interspecies hydrogen transfer on thermophilic protein and amino acid metabolism. $\mathrm{PhD}$ thesis, Department of Microbiology, Swedish University of Agricultural Sciences: Uppsala, Sweden.

Oude Elferink, S. J. W. H., Rinia, H. A., Bruins, M. E., de Vos, W. M. \& Stams, A. J. M. (1997). Detection and quantification of Desulforhabdus amnigenes in anaerobic granular sludge by dot blot hybridization and PCR amplification. J Appl Microbiol 83, 102-110.

Owen, R. J., Hill, L. R. \& Lapage, S. P. (1969). Determination of DNA base composition from melting profiles in dilute buffers. Biopolymers $\mathbf{7}$, 503-516.

Plugge, C. M, Zoetendal, E. G. \& Stams, A. J. M. (2000). Caloramator coolhaasii sp. nov., a glutamate-degrading, moderately thermophilic anaerobe. Int J Syst Evol Microbiol 50, 1155-1162.

Rainey, F. A., Ward-Rainey, N. L., Janssen, P. H., Hippe, H. \& Stackebrandt, E. (1996). Clostridium paradoxum DSM $7308^{\mathrm{T}}$ contains multiple 16S rRNA genes with heterogeneous intervening sequences. Microbiology 142, 2087-2095.

Rees, G. N., Harfoot, C. G. \& Sheehy, A. J. (1998). Amino acid degradation by the mesophilic sulfate-reducing bacterium Desulfobacterium vacuolatum. Arch Microbiol 169, 76-80.

Scholten, J. C. M. \& Stams, A. J. M. (1995). The effect of sulfate and nitrate on methane formation in a freshwater sediment. Antonie Leeuwenhoek 68, 309-315. 
Slobodkin, A., Reysenbach, A.-L., Mayer, F. \& Wiegel, J. (1997). Isolation and characterization of the homoacetogenic thermophilic bacterium Moorella glycerini sp. nov. Int $J$ Syst Bacteriol 47, 969-974.

Stams, A. J. M. \& Hansen, T. A. (1984). Fermentation of glutamate and other compounds by Acidaminobacter hydrogenoformans gen. nov., sp. nov., an obligate anaerobe isolated from black mud. Studies with pure cultures and mixed cultures with sulfate-reducing and methanogenic bacteria. Arch Microbiol 137, 329-337.

Stams, A. J. M., Grolle, K. C. F., Frijters, C. T. M. J. \& Van Lier, J. B. (1992). Enrichment of thermophilic propionate-oxidizing bacteria in syntrophy with Methanobacterium thermautotrophicum or Methanobacterium thermoformicicum. Appl Environ Microbiol 58, 346-352.

Stams, A. J. M., van Dijk, J. B., Dijkema, C. \& Plugge, C. M. (1993). Growth of syntrophic propionate-oxidizing bacteria with fumarate in the absence of methanogenic bacteria. Appl Environ Microbiol 59, 1114-1119.

Strunk, O. \& Ludwig, W. (1991) ARB: a software environment for sequence data. Department of Microbiology, Technical University of Munich, Munich, Germany. http://www.mikro.biologie.tu-muenchen.de/
Tarlera, S. \& Stams, A. J. M. (1999). Degradation of proteins and amino acids by Caloramator proteoclasticus in pure culture and in coculture with Methanobacterium thermoformicicum Z245. Appl Microbiol Biotechnol 53, 133-138.

Tarlera, S., Muxí, L., Soubes, M. \& Stams, A. J. M. (1997). Caloramator proteoclasticus sp. nov., a new moderately ther-mophilic anaerobic proteolytic bacterium. Int J Syst Bacteriol 47, 651-656.

Thauer, R. K., Jungermann, K. \& Decker, K. (1977). Energy conservation in chemotrophic anaerobic bacteria. Bacteriol Rev 41, $100-180$.

Wasserfallen, A., Nölling, J., Pfister, P., Reeve, J. \& Conway de Macario, E. (2000). Phylogenetic analysis of 18 thermophilic Methanobacterium isolates supports the proposals to create a new genus, Methanothermobacter gen. nov., and to reclassify several isolates in three species, Methanothermobacter thermautotrophicus comb. nov., Methanothermobacter wolfeii comb. nov., and Methanothermobacter marburgensis sp. nov. Int J Syst Evol Microbiol 50, 43-53.

Zoetendal, E. G., Akkermans, A. D. L. \& de Vos, W. M. (1998). Temperature gradient gel electrophoresis analysis of $16 \mathrm{~S}$ rRNA from human fecal samples reveals stable and host-specific communities of active bacteria. Appl Environ Microbiol 64, 3854-3859. 